\title{
THE FOSTER CARE BACKLOG: A THREAT TO THE RETENTION OF SOCIAL WORKERS?
}

\section{Phindile Ngwenya, Petro Botha}

\section{INTRODUCTION}

Social workers are seen as a key resource in addressing the needs of South African society (Department of Social Development, 2009:7). The Department of Social Development (DSD) employs the bulk of social workers in the country to implement policies and programmes targeting, for example, poverty, unemployment and HIV/AIDS. However, the government is faced with an overwhelming demand for services and the inability of social workers to cope with these demands. According to the Recruitment and Retention Strategy for Social Workers (Department of Social Development, 2009:7), this lack of capacity is the result of a critical problem with the recruitment of social workers and the fact that recruited social workers cannot be retained either in the government or within the profession in general. Social workers move between the government, NGOs, and the private and corporate sectors. Social workers also migrate to other fields or other countries because of better job opportunities. The Department of Social Development (2009:7) acknowledges the role of the poor working conditions of social workers: "The inability of the sector to retain social workers is further exacerbated by lack of support and the poor working conditions that social workers are subjected to, which often lead to burnout and inability to render effective services."

One of areas in which social workers have been unable to cope because of an overwhelming demand for services is foster care. The backlog in foster care applications has been an issue in the Johannesburg office of the Department of Social Development for the last number of years, resulting in foster care placement applications accumulating. The social workers are inundated with high caseloads and foster care applications could take up to a year or longer before they are processed and finalised at the Children's Court. The researcher explored the factors contributing to, as well as the consequences of, the foster care backlog. She also made recommendations on how the backlog can be addressed from the perspective of the social workers as service providers. Factors such as high caseloads, a high turnover of social workers, lack of resources, lack of support and training from management are some of the research findings. Recommendations based on the study include filling of vacant posts immediately, employment of more supervisors, equal distribution of caseloads, regular section meetings, adequate resources and infrastructure, and management visibility at grassroots level.

One of the factors contributing to the foster care backlog is the high turnover of social workers, as a result of low salaries and migration. Positions are often not filled, allowing the backlog to grow further. When a social worker is finally appointed, she is met with a huge backlog, leaving her feeling overwhelmed. This worker usually resigns quickly, again contributing to the high turnover cycle. The purpose of this article is to draw attention to the alarming link between the findings of this research study and factors associated with the departure of social workers, not only from the field of child welfare, but also from the profession. In order for the Department of Social Development to achieve its legal mandate and render quality service to its clients, it is of the utmost importance to secure a well-trained and stabilised workforce in the field of foster care. 


\section{RETENTION OF SOCIAL WORKERS}

Retention of social workers is not only problematic for South Africa, but for many other countries such as Australia, the United Kingdom, Ireland, Sweden and the United States (Cauvain, 2010:20). The problem of retention has also been described in specialised social work fields, e.g. child welfare, mental health and substance abuse (Huxley, Evans, Gately, Webber, Mears, Pajak, Kendall, Medina \& Katona, 2005; Scannapieco \& Connell-Carrick, 2007; Vermeulen, 2007). Specific attention has been given to public child welfare services (Cahalane \& Sites, 2008; Dickinson \& Perry, 2002; Westbrook, Ellis \& Ellett, 2006). In the last 10 years several research studies have been conducted in South Africa focusing on the retention of social workers as well as the related themes of work stress and job satisfaction of social workers (Adlem, 2007; Fortuin, 2005; Lukelelo, 2004; Sela, 2001; Vermeulen, 2007). Many of these studies identify the cost of a high turnover or departure of social workers as well as factors associated with the turnover or departure of social workers, and they make recommendations on how social workers can be persuaded to stay within a specific organisation, field or the profession.

\section{THE COST OF STAFF TURNOVER OR DEPARTURE}

Different studies in the USA have reported various annual turnover rates of social workers within the child welfare sector. From a 2001 study Yamatani, Engel and Spjeldnes (2009:362) report that turnover rates vary between 30 and 60 per cent, while Westbrook et al. (2006:38) refer to rates ranging from 20 to 40 per cent based on studies done in 2001, 2003 and 2005. In September 2011 the Department of Social Development initiated a national evaluation of their Recruitment and Retention Strategy for Social Workers. This study should provide information on the turnover rates of social workers in South Africa.

The cost of the departure of social workers is high. Direct costs entail separation costs, for example, separation pay and unemployment tax; rehiring cost, for example, advertising the vacancies, pre-employment activities; and training costs such as formal and on-the-job training. It can also take between 7 to 13 weeks to fill a position (Yamatani et al., 2009:362). Indirect costs include lower staff morale, lower productivity and burnout of workers remaining, who often have to take over the job responsibilities of the person who has left. A negative cycle of turnover, which is difficult to break, can be created: "high staff turnover tends to lead to high vacancy rates, which increase the workloads of those workers remaining. Increased workloads lead to frustration, poor services and eventually more turnover" (Cahalane \& Sites, 2008:93). Huxley et al. (2005:1070) also refer to this turnover cycle, which contributes to low job satisfaction and emotional exhaustion of workers who stay.

Experience is lost and staff remaining do not always have enough knowledge and experience to supervise their peers. As clients are shifted from worker to worker, understanding of their unique needs and trust deteriorate. Lower wellbeing among clients who had developed a rapport with the worker who left was also reported. Investigations take longer to be completed and the standard of services to the public is influenced (Chalane \& Sites, 2008:92; Vermeulen, 2007:95-96; Westbrook et al., 2006:39; Yamatani et al., 2009:362).

\section{FACTORS ASSOCIATED WITH THE TURNOVER OR DEPARTURE OF SOCIAL WORKERS}

Research divides factors associated with the turnover or the retention of social workers into two or three categories. Westbrook et al. (2006:37) and Lee, Rehner and Foster (2010:175) 
differentiate between personal and organisational factors, while Cahalane and Sites (2008:94) divide variables into personal characteristics, work factors and agency factors. In this discussion work and agency factors will be included under organisational factors.

\section{Personal factors}

Professional commitment to the field of child welfare and the welfare of others is found to strongly influence a social worker's intention to remain employed, as does an experience of self-efficacy. Burnout is often associated with turnover and is divided into three subdimensions: emotional exhaustion (feeling emotionally drained by contact with others), depersonalisation (negative feelings and cynical attitudes towards clients) and reduced personal accomplishment (tendency to evaluate one's own work negatively) (Westbrook et al., 2006:4142). Personal problems, a lack of training and a negative attitude toward the profession are also identified as personal factors associated with the departure of social workers (Adlem, 2007:6667). The length of service and level of further education influence retention of social workers. The longer experience social workers have, the less likely they are to leave. The first three years of service in the field are decisive in decisions to stay or leave (Chenot, Benton \& Kim, 2009:130; Evans \& Huxley, 2009:264). Chenot et al. (2009:142) found that those with a MSW qualification were less likely to stay in the field of child welfare.

\section{Organisational factors}

According to Cahalane and Sites (2008:96), the organisational climate, defined as the collective perception that employees have of their work environment, plays an important role in the retention of social workers. The climate may consist of salary and other promotional opportunities, caseload, fellow employee trust, quality of supervision, acceptance of worker autonomy and whether there are enough resources to do the work.

High workloads have been consistently cited as a reason for the departure of social workers (Cahalane \& Sites, 2008:95). Yamatani et al. (2009:361) distinguish between "workloads" as the time involved in completing tasks and "caseloads" as time spent with clients. It is difficult to determine the ideal caseload, the number of cases manageable by workers without compromising service quality. Yamatani et al. (2009:362) refer to 15 active investigations and a maximum of 15 to 30 open cases as a guideline set for child welfare workers. The Integrated Service Delivery Model (Department of Social Development, 2005:39) suggests the ratio of caseload to case manager in South Africa to be 1 to 60. A too high caseload has a detrimental effect on the wellbeing of clients and staff.

Quality supervision is highlighted by most research studies as an important factor in the retention of social workers (Cahalane \& Sites, 2008:106; Chenot et al., 2009:13; Warman \& Jackson 2007:36). Westbrook et al. (2006:42) summarise quality supervision as understanding of the responsibilities and demands of child welfare work, distributing workload in a fair or equitable manner, availability, flexibility, good listening skills, respect for workers' point of view, adequate knowledge, providing instrumental and emotional support, realistic expectations, concrete feedback and praise for a job well done. The importance of "socialisation" of new workers in organisations has also been mentioned (Chenot et al., 2009:144). Although support from a supervisor seems to weigh more, peer support has also emerged as a significant factor in many studies (Chenot et al., 2009:131; Scannapieco \& Connell-Carrick, 2007:33).

Role conflict where workers feel their work performance is negatively influenced by pressure to engage in conflicting or mutually exclusive behaviours, as well as inadequate time and 
resources, contributes to turnover of staff (Cahalane \& Sites, 2008:106). This happens when social workers are pressurised to meet "targets" without considering the needs of clients (Cauvain, 2010:20).

Social workers leaving organisations or the profession are often characterised by a sense of job dissatisfaction. They perceive little opportunity to make use of their skills or to use their own judgment, and feel they get little recognition for doing a good job. A lack of prestige in the community and negative publicity in the media further contribute to the feeling of dissatisfaction (Cahalane \& Sites, 2008:105).

\section{RETENTION STRATEGIES}

Various retention strategies are recommended in the literature. More permanent social workers should be recruited and experienced staff should be encouraged to remain in employment (Warman \& Jackson, 2007:37). This will help to reduce the caseloads of workers. Evans and Huxley (2009:265) stress the importance of good case management, while Scannapieco and Connell-Carrick (2007:48) suggest that new workers should be allowed to get a gradual caseload and not arrive on the first day to a full caseload.

Improved remuneration and compensation which include monetary benefits, e.g. bonuses linked to contracts, retention allowances, merit awards, bursary schemes, as well as nonmonetary strategies, e.g. additional leave, sabbaticals, job rotation, could improve retention (Adlem, 2007:82-86). The importance of career ladders and promotional opportunities are highlighted (Blosser, Cadet \& Downs, 2010:172). The profession could be marketed to improve the image of social workers through, for example, mass outreach programmes, media campaigns and brochures (Huxley et al., 2005: 1077).

More supervisors should be appointed and trained to render quality supervision. Various models of supervision and peer support such as group discussions could be utilised (Chenot et al., 2009:144; Warman \& Jackson, 2007:38). As part of transparent management, employers should monitor staff morale on a regular basis and listen to what their staff have to say and act upon their concerns where possible (Evans \& Huxley, 2008:265). Employers should recognise their staff as central in the delivery of quality services and give recognition for good work (Morris, 2005:353).

The findings of a study on the factors contributing to the foster care backlog (Ngwenya, 2011) in the Johannesburg office of the Department of Social Development show alarming correspondence between personal and organisational factors associated with the turnover and the departure rate of social workers. Even the suggestions on how the backlog could be addressed show similarities to retention strategies presented in literature. The next section will discuss this research and its findings will be linked to relevant literature on the retention of social workers.

\section{THE FOSTER CARE BACKLOG IN THE JOHANNESBURG OFFICE OF THE DEPARTMENT}

Foster care in South Africa has greatly expanded in recent years as a consequence of the AIDS epidemic and a policy adopted in 2000 to legalise the placement of children with extended family members (UNICEF, 2010). According to the Department of Social Development's annual report 2010/2011 (2011:72), 510713 children are in foster care in South Africa. 
An increase in foster care applications and a growing backlog in service delivery, negatively impacts which on the quality of services rendered, were observed in the Johannesburg office of the Department of Social Development. This office consists of the bigger Johannesburg office and the sub-offices of Lenasia, Midrand, Senaoane (Soweto) and Alexandra. Upon application, the clients wait for six to twelve months before they are screened. In the 2005/2006 annual report the Department of Social Development (2006:6) mentioned the increase in the foster care backlog. The MEC for Social Development took the initiative to prioritise and focus on the issue of the foster care backlog from 2006. The Johannesburg office of the Department of Social Development defines a backlog as all the cases not attended to in a six-month period or more. Despite a programme to accelerate foster care placements, the backlog in this office is still accumulating. In October 2007 the office had 4000 foster care applications that needed to be finalised or completed. By April 2008 the backlog had increased to an estimated 10528 foster care applications. The estimated monthly intake was 400. The office had 91 field social workers doing foster care. Each social worker was expected to screen the clients, finalise the matter for the Children's Court, and monitor and supervise the placement. This backlog and the factors contributing to the situation served as motivation for the researcher to investigate the topic and to put forward suggestions on how the problem can be curbed (Ngwenya, 2011:4-6).

\section{RESEARCH GOAL AND OBJECTIVES OF THE RESEARCH STUDY}

According to De Vos, Strydom, Fouché and Delport (2002:107), the researcher has to decide consciously what the research goal and objectives are going to be. The goal of this research study was to explore and describe the factors contributing to the foster care backlog and to make suggestions to resolve this problem from a service provider's perspective. The objectives focused on the reasons for the foster care backlog, the consequences of the foster care backlog in social work service, and offering suggestions on how this backlog could be addressed.

\section{RESEARCH METHODOLOGY}

A qualitative approach to better understand the phenomenon of the foster care backlog was utilised, since qualitative research emphasises the depth of the understanding and the deeper meanings of human experience (Rubin \& Babbie, 1997:272). An explorative, descriptive and contextual research design was used, as no other studies exploring the foster care backlog in South Africa could be found and the research specifically focused on the foster care backlog in the specific context of the Department of Social Development's Johannesburg office.

The population for this study included all social workers from the Department of Social Development's Johannesburg office who were in the foster care division, namely production and advanced production. Production refers to junior social workers and advanced production means senior workers doing statutory services in foster care. The population consisted of 91 foster care social workers. Non-probability, purposive sampling was used in identifying and selecting 30 participants in this study.

Focus group interviews were held with 6 to 8 social workers from each sub-office, 30 in total. Participants were asked about their perception of what a backlog is, what the reasons for the foster care backlog are, what they perceive as the consequences of the backlog in social work practice, and what in their opinion could be done to address the foster care backlog.

The steps of data analysis as suggested by Padgett (1998:73-74) were followed. All recorded sessions were listened to, themes were identified, data were classified into categories, and these data were interpreted to draw final conclusions. Four aspects which ensured trustworthiness as 
described by Guba's model (in Krefting, 1991:214-222) were applied, namely truth value, applicability, consistency and neutrality.

\section{RESEARCH FINDINGS}

For the purpose of this article, the authors will present the findings of the study and link them to literature on the retention of social workers. It seems that the foster care backlog creates a serious threat to the retention of social workers within the field of child welfare and the profession.

\section{The profile of the participants}

Focus group interviews were conducted with four groups and a total of 30 foster care social workers. Six males and 24 females were included in the study. They were all black and their work experience ranged from 10 months to 23 years. Fifteen social workers had been employed for a year or less, which reflects a high level of staff turnover. Twenty workers were employed for three years or less and only three workers had eight years or more experience. The profile of the participants reflected that $80 \%$ of social workers who were employed at the Johannesburg office had little or no experience of foster care. The majority came straight from university.

A personal factor related to the retention of social workers, is the number of years experience. The longer experience social workers have, the less likely they are to leave. The first three years of service in the field are decisive in decisions to stay or leave (Chenot et al., 2009:130; Evans \& Huxley, 2009:264). Not only do the findings indicate a high level of turnover of social workers, but also a loss of valuable knowledge and experience in the field. Taking the literature into account, this could mean that $67 \%$ of the staff find themselves at a stage of their career at which they decide to stay or leave their employer.

\section{Reasons for the foster care backlog}

Three themes were identified in the reasons given by participants for the foster care backlog. These themes with the relevant sub-themes are summarised in Table 1. Reasons for the foster care backlog which correspond with factors associated with the retention of social workers will be discussed in detail.

\section{A high turnover of staff}

The link between the foster care backlog and a high staff turnover, the focus of this article, was clearly underlined in the findings. Organisational factors namely insufficient remuneration, a lack of human resources and the turnover cycle, were indicated:

"The resignation of social workers and not filling the post, maybe they will take three to four months or more to employ another social worker that also cause backlog. The new social worker will struggle because she/he is new from the different place so he will struggle."

"Social workers are not paid well, they migrate and immigrate to other countries for greener pastures.” (Cahalane \& Sites, 2008:96) 
TABLE 1

\section{REASONS FOR THE FOSTER CARE BACKLOG}

\begin{tabular}{|c|c|}
\hline Theme & Sub-themes \\
\hline \multirow[t]{3}{*}{$\begin{array}{l}\text { Social } \\
\text { workers }\end{array}$} & $\begin{array}{l}\text { High caseload: Social workers are inundated with high volumes of cases and are still } \\
\text { expected to cope with a variety of tasks. }\end{array}$ \\
\hline & $\begin{array}{l}\text { Unequal distribution of files: Caseloads are unevenly distributed according to area; there } \\
\text { are workers who have more cases than others. }\end{array}$ \\
\hline & $\begin{array}{l}\text { High turnover of staff: Social workers leave as a result of low salaries and migration. } \\
\text { Positions are often not filled, allowing the backlog to grow further. When a social worker } \\
\text { is finally appointed, he/she is met with a huge backlog, leaving this worker feeling } \\
\text { overwhelmed and he/she usually resigns quickly, again contributing to the high turnover } \\
\text { cycle. }\end{array}$ \\
\hline \multirow[t]{2}{*}{ Clients } & $\begin{array}{l}\text { Poor cooperation of clients: Clients are sometimes not honest and cooperative; they give } \\
\text { false information and don't notify social workers when they move away. They don't bring } \\
\text { outstanding documents in time and leave the responsibility of caring for the foster child to } \\
\text { other people not appointed to do so. }\end{array}$ \\
\hline & $\begin{array}{l}\text { Influx of clients from rural areas: Clients from rural areas often come to Johannesburg } \\
\text { in the hope that they will receive more effective service delivery from the Department of } \\
\text { Health and Social Development. }\end{array}$ \\
\hline \multirow[t]{8}{*}{$\begin{array}{l}\text { Manage- } \\
\text { ment }\end{array}$} & $\begin{array}{l}\text { Lack of support and training from management and supervisors: Participants } \\
\text { indicated that management does not give support or take care of the social workers. There } \\
\text { is not enough supervision, and there is no proper training provided to newly employed } \\
\text { social workers in terms of policies and legislation regarding foster care. Social workers } \\
\text { don't understand what is required in terms of the work given to them. }\end{array}$ \\
\hline & Insufficient supervisors: The number of supervisors appointed is insufficient. \\
\hline & $\begin{array}{l}\text { Red tape and poor administration: It takes up to six months for a file to go through the } \\
\text { administrative process before it reaches the social worker. Clients are sent from one } \\
\text { department to the next, and files are also allocated to vacant posts. Keeping record of the } \\
\text { backlog takes up further time. }\end{array}$ \\
\hline & $\begin{array}{l}\text { Insufficient consultation and communication with staff: The participants saw } \\
\text { communication and staff consultation as very important. Management needs to know and } \\
\text { understand the challenges encountered by the personnel. }\end{array}$ \\
\hline & $\begin{array}{l}\text { Poor implementation of departmental strategies: In } 2005 \text { and } 2006 \text { contract workers } \\
\text { were employed to each finalise } 20 \text { cases per month. Although this assisted with opening } \\
\text { and finalisation of cases, there were not enough social workers to do supervision, which } \\
\text { again had a negative impact on the caseloads of foster care workers. The very files which } \\
\text { were opened and finalised were taken back to area workers to extend court orders, rather } \\
\text { than this being done by the contract workers who had opened and finalised them. This } \\
\text { increased the number of cases in area social workers' caseloads. }\end{array}$ \\
\hline & $\begin{array}{l}\text { Lack of resources: The participants mentioned the lack of resources, which included the } \\
\text { lack of human resources, offices, stationery, cars, computers and telephone and fax } \\
\text { facilities. }\end{array}$ \\
\hline & $\begin{array}{l}\text { Role of politicians: Participants highlighted the role of politicians in advocating foster } \\
\text { care grants as a solution to poverty. }\end{array}$ \\
\hline & $\begin{array}{l}\text { Inconsistency of Commissioner at the Children's Court: The Commissioners in the } \\
\text { Children's Courts appear to have different points of view in terms of the data needed to } \\
\text { finalise the case. }\end{array}$ \\
\hline
\end{tabular}




\section{High caseloads and unequal distribution of cases}

On 8 April 2010 the caseload of the Alexandra office was 1310 supervision cases (cases that have been finalised at the Children's Court), 99 new applications (cases that have not been finalised by court) older than six months and 91 less than six months old, with 11 social workers and 5 auxiliary social workers. In the Midrand office the caseload was 900 new cases and supervision cases with 10 social workers and 7 auxiliary social workers. In the Senaoane (Soweto) office the caseload was 1039 new cases and supervision cases, with 13 social workers and 6 auxiliary social workers. The Lenasia office caseload was 1500 , with 11 social workers and 5 auxiliary social workers. The Lenasia office thus carried the heaviest caseload, followed by the Alexandra office. The caseloads of individual workers also differed: during the focus group interviews some social workers mentioned caseloads of 80 cases, 120 cases and 200 cases:

"The ratio of cases per social worker is too high.... I have one hundred and seventy something files to attend to - what about supervision 16(2), 33s? We're doing many things and uncontrollable cases, we're doing adoption."

“... files are not distributed evenly to area social workers..." (Ngwenya, 2011:39)

Comparing this to the American ideal of 15-30 cases, it is clear that the caseloads of both the relevant offices and the individual workers were unrealistically high. As an organisational factor, high caseloads are one of the most decisive factors in social workers' decision to leave. High caseloads have also been noted as a common factor in stress, job burnout and job dissatisfaction (Yamatani et al., 2009:361).

\section{Lack of quality supervision and administrative support}

The study indicated a lack of supervisory and administration support as important reasons for the foster care backlog. There aren't enough supervisors, and supervisors are not adequately trained. This results in workloads not being monitored effectively and new staff not being adequately inducted. Red tape further slows down the process, for example, clients are not informed from the beginning about requirements, such as documentation.

"The backlog is not only on social workers, supervisors are bombarded with many social workers, doesn't meet the ratio level, the supervisor per social workers. They have to canalise many cases."

"We are coming in the field you find that again you don't get necessary support in terms of understanding what is exactly that is required and how, you still to fill in that way, I mean the Department does not help in putting structures in place to prepare those newly appointed workers to actually fit in, I mean the supervisory measures are not of quality in a sense."

One of the factors most highlighted by research as playing an important role in the retention of social workers is quality supervision (Cahalane \& Sites, 2008:106; Chenot et al., 2009:13; Warman \& Jackson, 2007:36). It thus seems that staff who are carrying an excessive caseload without the support of quality supervision and adequate training run a risk of high turnover or departure.

\section{Insufficient consultation and communication with staff}

From the findings it was clear that there is a need for more open communication with management. The participants felt that management should know and understand the challenges encountered by staff and not be seen as only counting cases and policing them: 
"From Management people need to come down to us and listen to us what are the challenges, so no one, they will send you a paper work, the paper work is flowing from top levels and down to us to try to police us in what we're doing, but there're major problems down there. Now you can hear there's a problem between social workers and social auxiliary workers. The Department itself has created this problem, basically because of the new Act adapting to it."

A positive organisational climate which includes open communication, trust and autonomy of workers contributes to the retention of staff (Cahalane \& Sites, 2008: 96).

\section{Consequences of the foster care backlog for the social workers and the profession}

In the findings three themes relating to social workers, clients and the profession were identified in the consequences of the foster care backlog.

\section{Theme 1: Consequences for social workers}

The participants indicated that the backlog has made them lose self-esteem and feel helpless and deskilled, not utilising social work skills. Instead they are "pushing numbers". They said that they felt demotivated, demoralised, threatened and emotionally taxed since they worked under pressure. One member stated that it also affected their social and home life, since they were always tired. The quality of their work was affected. The participants felt disrespected and undermined by other professions and management.

"Demoralises me, de-motivates you, you get tired you don't want to do many things eish! You lose your self-esteem; sometimes you come here just to push the day to be out of your work, after you just come to push and at the end of the month you get paid, that's all."

"Helpless, you feel as if there's somebody behind you with a baton waiting for you to produce the number and we need to run in order not to be hit by that baton."

Social workers feel disillusioned with their work. They do not see the meaning in what they do, they are not doing what they studied for and do not see a future. Their work is equated to numbers of cases finalised.

"I'm busy managing problems to an extent that I'm failing to have contact with the people, to go to the real need because this is not the real need. I want to go to the people, work with the people, hear what the people stories are and help them to change their lives."

"Backlog is impacting on us 'cause is reducing our growth as social workers. You can't grow and then we're getting nowhere as social workers."

"Our performance is evaluated based on numbers so, if my profession says I must move with the client and my employer expects me to finalise a certain number of case per month, then you know as human beings we do get our salaries and money is also important to us, that is why we end up finalising more, trying to finalise more with the little information we have, so that we can reach the number and that will mean money to me at the end of the day."

The social workers feel they cannot render quality work:

"In my opinion I think it also makes us to work under pressure at the end of the day we want to speed up the process, but at the end we end up doing mistakes by not getting 
full information like in terms of the client just want to speed up the process, then you do mistakes."

"Our performance is evaluated based on numbers so, if my profession says I must move with the client and my employer expects me to finalise a certain number of case per month then you know as human beings we do get our salaries and money is also important to us, that is why we end up err finalising more, trying to finalise more with the little information we have, so that we can reach the number and that will mean money to me at the end of the day."

These findings are extremely alarming, indicating that the wellbeing of social workers having to cope with such a backlog is being seriously compromised. Comparing the findings with the literature, it seems that workers are experiencing burnout. All the dimension of burnout, namely emotional exhaustion, depersonalization of clients and a sense of reduced personal accomplishment, can be identified (Westbrook et al., 2006:41-42). Workers are clearly experiencing role conflict in that they are pressurised to meet "targets" without considering the needs of clients (Cahalane \& Sites, 2008:106; Cauvain, 2010:20). These personal and organisational factors can convince workers to leave their organisation or the profession.

\section{Theme 2: Consequences for clients}

The participants in the focus groups agreed that the foster care backlog had a negative impact on service delivery. The clients were reduced to numbers and not empowered. When the cases were finalised, the clients were not provided with proper supervision services or family counselling. This also influenced the relationship between social workers and clients.

"We no longer mediate for our clients or advocate - like now I'm having a case of one child, this child was raped but the case is already opened and finalised so I no longer have time to give counselling or refer the child to other professionals like psychologists, because I had to concentrate on the backlog. She goes to court alone, I was supposed to be there sometimes to give support but we don't have time."

"You feel somehow as clients ask you how you work and you can't even answer that clients lose trust and don't trust you anymore."

"I remember before we had this huge backlog we used to conduct groups with foster parents, we no longer does that. Now we're chasing numbers of backlog."

These findings speak of a feeling of job dissatisfaction which characterises social workers who leave organisations or the profession. As described in the literature, these workers also perceive little opportunity to make use of their skills and suffer from a lack of prestige in the community (Cahalane \& Sites, 2008:105).

\section{Theme 3: Consequences for the profession}

The participants indicated that the foster care backlog "is killing the profession". Social workers are no longer the agents of change, but emergency workers. The Department of Social Development has forced social workers to "push numbers", which contradicts the Code of Ethics for Social Workers; since the social workers are evaluated on numbers, they no longer render quality services. Clients and people from other professions lose trust in and respect for social work.

"I think with my experience in working in the social work field, it has changed my concept of what social workers are supposed to do. I don't see myself as a social 
worker but an emergency worker now. To an extent that I don't even enjoy the profession. If you try to be honest we're contradicting the code of ethics of social work."

"I think another thing is in terms of the impact the caseload has on us and the profession. This thing is sending out the bad name to us as social workers you understand because even the clients outside don't respect you as a social worker."

"I feel we've been turned into machines that are manufacturing tickets to money 'cause we're no longer dealing with children in need of care but children in need of cash. ... What we are looking for is the information that will fit into what the Department of Justice want to declare children as children in need of care and you even end up, how can I put it 'raping the Children's Act' to force it to look at the situation the way I want it to be looked at. I want this case to be finalised so that I can deal with other cases which are behind."

Cole, Panchanadeswaran and Daining (2004:8) refers to a study on job satisfaction which found that participants who felt that they were able to affect positive change with their clients and made meaningful contributions at work were satisfied with their job regardless of the level of workload. The storylines in this research speak not only of role conflict, but of a total disillusion with the social work profession. This negative image of social work can lead not only to the departure of social workers from the field, but can also make it difficult to recruit new social workers.

\section{RECOMMENDATIONS TO ADDRESS THE FOSTER CARE BACKLOG}

The following recommendations are made based on the research findings. They will contribute not only to the reduction of the foster care backlog, but also directly and indirectly to the retention of social workers working with foster care within the Department of Social Development. Where applicable, the recommendations are linked with the literature on the retention of social workers.

\section{Induction of newly appointed social workers}

In any organisation the newly employed staff undergo intensive training to equip them with working skills to ensure effectiveness and efficiency in terms of the job required. It is recommended that newly appointed social workers be trained in foster care before they are put in the "backlog dungeon" with no proper knowledge and skills.

Adequate training and induction of new staff members are recognised as an important retention strategy. Scannapieco and Connell-Carrick (2007:48) even suggest that new workers should be allowed to get a gradual caseload and not arrive on the first day to a full caseload.

\section{Division of foster care services}

If one social worker is responsible for opening and finalising cases, conducting investigations and doing supervision at the same time, this could result in poor service delivery and low productivity. It is recommended that foster care services be divided. Some social workers need to focus on new applications and all the necessary procedures. Other social workers need to focus on supervision cases and all related procedures. This will alleviate the stress and frustration that social workers experience and enable them to render quality service to the clients. 


\section{Establishment of a social workers' forum}

It is evident from the findings that the social workers are burnt out, frustrated and demotivated. It appears that they don't have a platform to air their concerns, views and frustration. It would be desirable to establish an informal forum in the office that would be a platform to discuss challenges at the workplace and come up with solutions.

This idea corresponds with the retention strategy discussed in the literature, namely that managements who want to retain their staff need to listen to their needs and concerns (Evans \& Huxley, 2008:265). The suggested forum can serve as an informal strategy to attain this goal.

\section{Vacant posts to be filled as soon as possible}

A vacant post should be filled as soon as possible, at least within six weeks of the resignation of a social worker, to enhance effective quality service to the clients. This process can be implemented by advertising posts as soon as the resignation letter is handed over to the human resource department. Alternatively, previous applicants who went for interviews and did exceptionally well but were not appointed because of the limited number of position available could also be contacted. This could save resources and speed up the process.

Filling a vacant position as soon as possible will counteract the turnover cycle as described by Cahalane and Sites (2008:93): “...high turnover tends to lead to high vacancy rates, which increase the workloads of those workers remaining. Increased workloads lead to frustration, poor services, and eventually more turnover."

\section{Employment of more supervisors}

It was evident from the study that the supervisors are unable to properly fulfil their monitoring and evaluation tasks as required. Social workers do not get the supervision they need, which results in poor quality of work and adds to the backlog. If feasible, more supervisors could be appointed, so that social workers could receive the training and support they need.

One of the retention strategies which most sources mention is the appointment of sufficient trained supervisors who can render quality supervision (Chenot et al., 2009:144; Warman \& Jackson, 2007:38). Westbrook et al. (2006:42) describe quality supervision as including understanding of the responsibilities and demands of child welfare casework, fair/equal distribution of workload, flexibility, good listening skills, respect for the point of view of workers, instrumental and emotional support as well as praise for good work.

\section{Equal distribution of files}

The unequal distribution of cases indicates that the supervisors are not monitoring and evaluating work done by social workers; they thus do not know each worker's files or caseload. It is important to look at the caseloads of the different areas when social workers are appointed within the different offices to be able to distribute cases equally to the social workers.

One of the retention strategies mentioned by Evans and Huxley (2009:265) is good case management. Westbrook et al. (2006:42) include fair/equal distribution of workload as a characteristic of quality supervision.

\section{Regular section meetings}

An organisation that functions optimally usually has monthly meetings to identify and discuss the challenges that may hinder the progress and targets set. It is therefore recommended that supervisors put time aside, maybe on a monthly or six-weekly basis, depending on regional 
needs, to meet with their section in order to discuss issues pertaining to their work environment and other challenges.

Transparent management as a retention strategy includes open and regular communication. Section meetings can also serve as a forum where management can listen to their staff, facilitate their input and give staff the necessary recognition (Evans \& Huxley, 2008:265; Morris, 2005:353).

\section{Management visibility to social workers at grassroots level}

Based on the findings from the study, it seems that management are not aware of, or concerned about, the frustrations and challenges that the workers are facing. It is strongly recommended that management visit or arrange meetings with the staff to enhance efficiency and effectiveness at the workplace.

Huxley et al. (2005:1075) report that social workers who have a positive view of the way their employer treats them shows a higher commitment.

\section{Adequate resources and infrastructure}

It is imperative to have the necessary tools in order to execute one's duties as it is impossible to function effectively in an environment that lacks proper resources. It is recommended that adequate resources and infrastructure be provided by the department to satellite offices in order to allow people to work in a user-friendly environment. It must be taken into account that social work is a profession that values client self-determination, confidentiality and the principle of respect for the clients.

\section{Meeting between the Commissioner of the Children's Court and social workers}

In view of the findings from the study these two parties need to have a meeting and debate issues and requirements of the court to enable the social workers to iron out the confusion created by the court to deliver quality service. In order to open the channel of communication, it is important to involve grassroots social workers, management and the Commissioner of the Children's Court.

\section{CONCLUSION}

The Department of Social Development employs the bulk of social workers in the country to implement policies and programmes. However, the government is faced with an overwhelming demand for services and the inability of social workers to cope with these demands. One of areas in which social workers have been unable to cope as a result of an overwhelming demand for services is foster care. The backlog in foster care applications has been an issue in the Department of Social Development, Johannesburg office, for the last number of years, resulting in foster care placement applications accumulating. The social workers are inundated with high caseloads and foster care applications could take up to a year or longer before they are processed and finalised at the Children's Court. The researcher drew a purposive sample from 91 social workers working with foster care at the Johannesburg office of the Department of Social Development. Focus group interviews were conducted with four groups and a total of 30 foster care social workers. She also explored the reasons for the consequences of the foster care backlog. Suggestions on how the backlog can be addressed, were made from the perspective of the social workers as service providers.

One of the factors contributing to the foster care backlog is the high turnover of social workers as a result of low salaries and migration. Positions are often not filled, allowing the backlog to 
grow further. When a social worker is finally appointed, she is met with a huge backlog, leaving her feeling overwhelmed. This worker usually resigns quickly, again contributing to the high turnover cycle. The purpose of this article is to draw attention to the alarming link between the findings of this research study and factors associated with the departure of social workers, not only from the field of child welfare, but also from the profession.

The profile of participants in the research study indicated a high level of staff turnover. It also reflected that $80 \%$ of social workers who were employed at the Johannesburg office had little or no experience of foster care. Most experienced social workers left, with a loss of valuable knowledge and experience to the field. From the findings on the reasons for the foster care backlog, high caseloads and unequal distribution of cases, the lack of quality supervision and administrative support, as well as insufficient consultation and communication with staff showed clear correspondence with organisational factors linked to the turnover and departure of social workers. Findings on the consequences of the foster care backlog for the social workers and the profession linked clearly with the literature on personal and organisational factors associated with social workers leaving. They have lost their self-esteem and feel helpless, demotivated and deskilled. They experience a serious role conflict, being expected to "push numbers" without making a real difference to the lives of their clients. Because of the high caseloads social workers are unable to render quality service, which impacts negatively on the wellbeing of their client as well as on their relationship with the community. Social workers are disillusioned with the profession, feel that they are "killing the profession" and that they even behave unethically to reach the targets set.

The recommendations of the study can directly and indirectly contribute to the retention of social workers within the field of foster care. Most of the suggestions made by participants correspond with retention strategies described in the literature. The researcher recommends that new social workers should be well prepared and inducted; foster care services should be divided; the caseload be equally distributed; and vacant posts filled as soon as possible. More communication and participation of workers can be considered through a social workers' forum and regular section meetings. It is also suggested that management should be more visible at grassroots levels. Adequate resources which include more human resources in the form of more social workers and supervisors, as well as better communication between role players, specifically the Commissioner of the Children's Court and the social workers, could further contribute to the reduction of the foster care backlog as well as the retention of social workers. From these findings it thus seems that the foster care backlog within the Johannesburg office of the Department of Social Development does create a serious threat to the retention of social workers within the field of child welfare and the profession.

A limitation of this research study, however, is that it only focuses on the situation at the Johannesburg office of the Department of Social Development. Further research is thus necessary to investigate the foster care backlog and the influence this has on the retention of social workers in other offices and across other provinces, as well as within NGOs. It will also be valuable to investigate the situation in other fields of social work. The Department of Social Development has initiated two important research studies which should shed further light on caseloads and the retention of social workers. The first is a study informing a possible Customised Performance Management and Development System, which would include reference to the ideal caseloads of social workers, and the second a national evaluation of their Recruitment and Retention Strategy for Social Workers. 
To conclude, it seems that social workers in the field of foster care are overwhelmed with the demand for services and are unable to cope with these demands. It also seems that the foster care backlog does hold a serious threat to the retention of social workers and that steps need to be taken to ensure a well-trained and stabilised workforce in the field of foster care.

\section{REFERENCES}

ADLEM, A.G. 2007. Retensiestrategieë as teenvoeter vir vroeë beroepsverlating onder maatskaplike werkers. Pretoria: University of South Africa. (MA dissertation)

BLOSSER, J., CADET, D. \& DOWNS, L. 2010. Factors that influence retention and professional development of social workers. Administration in Social Work, 34:168-177.

CAHALANE, H. \& SITES, E.W. 2008. The climate of child welfare employee retention. Child Welfare, 87(1):91-114.

CAUVAIN, S. 2010. Social workers do not feel valued by either their employer or the general public. Social Work Now, (November):20.

CHENOT, D., BENTON, A.D. \& KIM, H. 2009. The influence of supervisor support, peer support, and organizational culture among early career social workers in child welfare services. Child Welfare, 88(5):129-147.

COLE, D., PANCHANADESWARAN, S. \& DAINING, C. 2004. Predictors of job satisfaction of licensed social workers: perceived efficacy as a mediator of the relationship between workload and job satisfaction. Journal of Social Service Research, 31(1):1-12.

DEPARTMENT OF SOCIAL DEVELOPMENT. 2005. Integrated Service Delivery Model. Pretoria: Government Printer.

DEPARTMENT OF SOCIAL DEVELOPMENT. 2006. Annual report, 2005-2006. Pretoria: Government Printer.

DEPARTMENT OF SOCIAL DEVELOPMENT. 2009. Recruitment and retention strategy for social workers. Pretoria: Government Printer.

DEPARTMENT OF SOCIAL DEVELOPMENT. 2011. Annual report for the year ended 31 March 2011. Pretoria: Government Printer.

DE VOS, A.S., STRYDOM, H., FOUCHÉ, C.B. \& DELPORT, CSL. 2002. Research at grass roots for the social science and human service professions. Pretoria: Van Schaik Publishers.

DICKINSON, N.S. \& PERRY, R.E. 2002. Factors influencing the retention of specially educated public child welfare workers. [Online] Available: http:/www.HawthornPress.com. [Rev 05/2011].

EVANS, S. \& HUXLEY, P. 2008. Factors associated with the recruitment and retention of social workers in Wales: employer and employed perspectives. Health and Social Care in the Community, 17(3):254-266.

FORTUIN, L. 2005. Die belewenis van werksbevrediging deur grondvlak maatskaplike werkers. Pretoria: University of South Africa. (MDiac(SW) Dissertation)

HUXLEY, P., EVANS, S., GATELY, C.,WEBBER, M., MEARS, A., PAJAK, S., KENDALL, T., MEDINA, J. \& KATONA, C. 2005. Stress and pressures in mental health social work: the worker speaks. British Journal of Social Work, 35:1063-1079. 
KREFTING, L. 1991. Rigor in qualitative research: the assessment of trustworthiness. The American Journal of Occupational Therapy, 45(3):214-222.

LEE, J., REHNER, T. \& FORSTER, M. 2010. Employees' intention to remain employed in child welfare: testing a conceptual model. Journal of Public Child Welfare, 4:174-197.

LUKELELO, N. 2004. An investigation of burnout amongst medical social workers in children's wards. Stellenbosch: University of Stellenbosch. (MA Thesis)

MORRIS, L. 2005. The process of decision-making by stressed social workers: to stay or leave the workplace. International Review of Psychiatry, 17(5):347-354.

NGWENYA, P.M. 2011. Factors contributing to the foster care backlog: service providers' perspectives and suggestions. Pretoria: University of South Africa. (MA dissertation MA(MH))

PADGETT, D.K. 1998. Qualitative methods: qualitative and quantitative approaches. Thousand Oaks: Sage Publications.

RUBIN, A. \& BABBIE, E. 1997. The practice of social research. California: Wadsworth.

SCANNAPIECO, M. \& CONNELL-CARRICK, K. 2007. Child welfare workplace: The state of the workforce and strategies to improve retention. Child Welfare, 86(6):31-52.

SELA, M. 2001. Exploring job satisfaction amongst government social workers in East London. Grahamstown: Rhodes University. (MSocSc Dissertation)

UNICEF. 2010. Protection for orphans and the vulnerable children. [Online] Available: http:/www.unicef.org/southafrica/protection 6633.html. [Rev 19/11/2011].

VERMEULEN, A. 2007. Understanding the work experiences, coping strategies and organizational retention in Gauteng in-patient substance abuse treatment clinics. Johannesburg: University of Witwatersrand. (MA Dissertation)

WARMAN, A. \& JACKSON, E. 2007. Recruiting and retaining children and families' social workers: the potential of work discussion groups. Journal of Social Work Practice, 21(1):3548.

WESTBROOK, T.M., ELLIS, J. \& ELLETT, A.J. 2006. Improving retention among public child welfare workers: what can we learn from insights and experiences of committed survivors? Administration in Social Work, 30(4):37-73.

YAMATANI, H., ENGEL, R. \& SPJELDNES, S. 2009. Child welfare worker caseload: what's just right? Social Work, 54(4):361-368.

Ms Phindile M Ngwenya, Department of Social Development, Johannesburg Regional Office; Ms Petro Botha, Department of Social Work, University of South Africa, Pretoria, South Africa. 